\title{
Analysis of nutlet morphological characteristics of some Iranian Ajuga L. taxa
}

\author{
SEYED MEHDI TALEBI ${ }^{1, \bullet}$, RAHELEH TABARIPOUR ${ }^{2}$, MAJID ESKANDARI ${ }^{3}$ \\ ${ }^{1}$ Department of Biology, Faculty of Sciences, Arak University, Arak, 38156-8-8349 Iran. Tel.: +98-863-4173317. \\ vemail: seyedmehdi_talebi@yahoo.com \\ ${ }^{2}$ Department of Plant Sciences, Faculty of Biological Science, Alzahra University. Vanak, Tehran, Iran \\ ${ }^{3}$ Iranian Research Institute of Plant Protection, Agricultural Research Education and Extension Organization. Tehran, Iran
}

Manuscript received: 27 July 2019. Revision accepted: 4 September 2019.

\begin{abstract}
Talebi SM, Tabaripour R, Eskandari M. 2019. Analysis of nutlet morphological characteristics of some Iranian Ajuga L. taxa. Biodiversitas 20: 2833-2840. Ajuga is one of the problematic Lamiaceae genera, which naturally grows in different parts of Iran. There are many discussions about infrageneric and infraspecific classifications of the genus and several synonyms were definite for its taxa. In the current study, we evaluated nutlet morphological characteristics from six Iranian taxa of the genus using Scanning Electron Microscopy (SEM) and Light microscopy (LM). In total, thirteen (four qualitative and nine quantitative) nutlet morphological variables were investigated, and the obtained data were analyzed using MVSP and SPSS software. Quantitative nutlet features varied among the studied taxa and ANOVA test revealed significant variations $(\mathrm{P}<0.01)$ for most of them. Moreover, PCA analysis showed some characteristics made more than $60 \%$ of variations. Some quantitative characteristics like nutlet and ventral sculpturing shapes were nearly stable among the taxa. But dorsal sculpturing shape and existence of exocarp cell indumentum highly varied among the taxa and could be used as distinguishing traits for identification of taxa. The studied taxa were divided into four groups in UPGMA dendrogram and also PCA and PCO plots of the nutlet features. CA. Joined plot revealed that each group had specific nutlet characteristic (s). Taxa arrangements were not similar to those have been definite for them in Flora Iranica and Flora of Iran. Furthermore, some infraspecific taxa must be redefinite. It is advised to use complementary molecular studies to better clearing species relationship, taxa position and rank in the genus.
\end{abstract}

Keywords: Ajuga, micromorphology, nutlet, taxonomy

\section{INTRODUCTION}

The genus Ajuga L. belongs to the subfamily Ajugoideae of Lamiaceae. Ajuga taxa have 5-50 cm tall, opposite leaves, with nonpermanent stylus, nutlets pale to dark brown, asymmetrical, ovoid or rectangular, with wrinkled surface, ca. 2-10 mm long. (Judd 2008; Jamzad 2012). Several investigations (Riaz et al. 2007; Atay et al. 2016) have revealed that Ajuga has fifty species with about 300 taxa, which are widespread in different parts of the world such as Asia, Europe, and Africa. Most species of the genus are Irano-Turanian elements that grow in mountainous habitats, however, some of them are considered as Hyrcanian elements and inhabit in forest. This genus is represented in Iran by 6 species including 11 taxa, which six of them are endemic (Jamzad 2012). Ajuga is one of the problematic Labiatae genera in Iran and in several cases, taxonomic rank/ position of its species altered in different flora. For example, A. orientalis L. (1753) has been defined as Bugula orientalis (L) by Miller in 1768, although its other name is $B$. oblique Moench (1794). Moreover, A. scoparia Boiss. (1846) changed to A. chamaecistus subsp. scoparia (Boiss.) by Rechinger f. in 1982 (Jamzad 2012; Rechinger 1982).

Recent studies (Movahhedin et al. 2016: Venditti et al. 2016: Toiu et al. 2018) have reported that many taxa of the genus are rich in diterpenes, iridoids, flavonoids, anthocyanins, ecdysteroids and also essential oils. Therefore, several species of Ajuga have been employed as medicinal plants in traditional medicine for treatment of various diseases such as diabetes, inflammation, pain, hypertension or gastrointestinal (Cocquyt et al. 2011). For instance, in Turkey, A. orientalis L. is used for hemorrhoids (Güneş and Özhatay 2011) and skin diseases (Koyuncu et al. 2010), in addition, A. chamaepitys (L.) Schreber is used for wound healing (Tümen et al. 2006), hemorrhoids, as diuretic and antivenom (Sarac and Ugur 2007).

Moreover, several investigations have demonstrated efficacy of Ajuga taxa as antioxidant, cytotoxic (Venditti et al. 2016), antimalarial (Cocquyt et al. 2011), hypolipidemic (El-Hilaly et al. 2006), anabolic, antibacterial, antifungal, cardiotonic and hepatoprotective agents (Israili and Lyoussi 2009).

Various evaluations are found about nutlet morphology and pericarp structure in Lamiaceae taxa (Husain et al. 1990; Demissew and Harley 1992; Ryding 1993, 1994; Marin et al. 1994; Oran 1996). Nutlet surface characteristics have been successfully applied in a range of systematic researches, and Scanning Electron Microscopy (SEM) has improved feature evaluation (Barthlott 1984; Husain et al. 1990; Marin et al. 1994; Oran 1996). However, taxonomically important traits of nutlet are 
surface sculpturing, exocarp cells type, anatomy of pericarp, and also indumentum (Roth 1977; Stace 1989).

Various investigations on nutlet features of certain genera in Labiatae family have confirmed that nutlet features are potentially useful within the family at different infrageneric ranks such as section and species (Marin et al. 1994; Ryding 1993, 1994).

In the current study, we investigated nutlet morphological characteristics of six Iranian Ajuga taxa using Scanning Electron Microscopy (SEM). The purposes of SEM study on the nutlet morphology of these taxa, which three of them (A. saxicola Assadi \& Jamzad, A. chamaecistus Ging. ex Benth subsp. tomentella (Boiss.) Rech. f., and A. chamaecistus Ging. ex Benth subsp. chamaecistus) have been definite as endemic taxa for Iran, were 1) to describe nutlet morphological characteristics of the studied taxa for the first time, 2) to solve problematic aspects of taxonomy and evolution, 3) these findings were useful in order to determine whether the seed characteristics can provide additional useful information for relationships at the subgeneric level of the genus or not. Because, Cantino (1992) and Ryding (1998) used different nutlet characteristics, including ultrastructure, surface morphology, and shape, in cladistic analyses within Lamiaceae. Moreover, Husain et al. (1990) also concluded that nutlets traits were very useful in providing evidence for phylogenetic reconstruction.

\section{MATERIALS AND METHODS}

\section{Plant material}

Nutlets were examined from six Ajuga taxa (three species, two subspecies, and a variety) (Table 1, Fig.1). We examined three nutlets obtained from each taxon after a number of plant specimens had been compared under stereomicroscope for similarity.

Plant materials used in the current research were from herbarium specimens deposited in the Herbarium Ministerii Iranici Agriculturae, Department of Botany (IRAN).

\section{Sample preparing}

For SEM investigation, Ajuga nutlets were observed using a stereomicroscope $(4 \mathrm{X})$ to ensure that they were of normal size and maturity (Jamzad 2012), then nutlets were mounted directly on aluminum stubs using double-sided adhesive and were sputter-coated with a thin layer (ca. 20 $\mathrm{nm}$ ) of gold. The SEM micrographs were taken in a SU SEM-3500 at an accelerating voltage of $15 \mathrm{kV}$.

Nutlets were investigated from various views, but when the sculpturing patterns differed at various views; both dorsal and ventral surfaces were used for description. Descriptive terminology was developed for shape, sculpturing pattern and cellular morphology. The descriptive terminology applied here is comparable to that used by Husain et al. (1990) and Stearn (1992). The terms given by Stearn (1992) are easy to follow and the descriptions presented there agree well with the patterns observed here. According to some valuable sources (Cantino 1992; Ryding 1998; Husain et al. 1990), thirteen qualitative and quantitative morphological features of nutlets were evaluated. They were: ventral length, ventral width, ventral length/width ratio, dorsal length, dorsal width, dorsal length/width ratio, aperture length, aperture width, aperture length/width ratio, nutlet shape, indumentum presence, dorsal and ventral sculpturing nature.

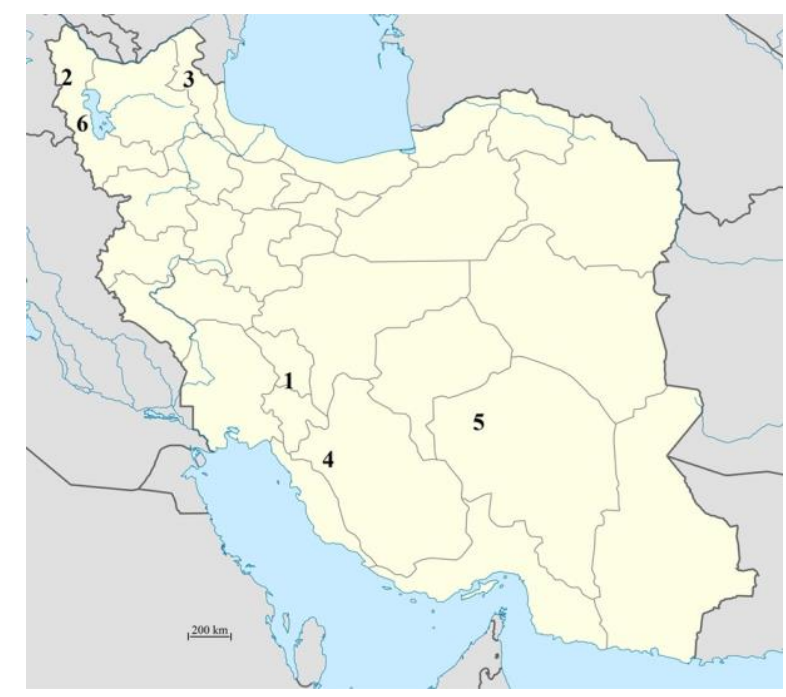

Figure 1. Distribution map of the studied Ajuga taxa in Iran

Table 1. The studied Ajuga L. taxa and their localities addresses

\begin{tabular}{|c|c|c|c|}
\hline Taxa & Locality & $\begin{array}{l}\text { Voucher } \\
\text { number }\end{array}$ & Distribution in Iran \\
\hline A. saxicola Assadi \& Jamzad (endemic) & $\begin{array}{l}\text { Kohkiloyeh: Basht, Tol Cheghah, Deh } \\
\text { Barabar to Sar Cheshmeh, } 1300 \text { m. }\end{array}$ & 22661-IRAN & West \\
\hline A. orientalis $\mathrm{L}$. & $\begin{array}{l}\text { Azerbaijan-W: Maku, Sari Chaman to } \\
\text { Kuhe Gherekhlar,2200 m. }\end{array}$ & 22615-IRAN & North, Northwest \\
\hline $\begin{array}{l}\text { A. chamaepitys (L.) Schreber. subsp. chia } \\
\text { (Schreber.) Murb. var. ciliata Briq. }\end{array}$ & Ardebil: Sarein, Ganzagh, 1450 m. & 22651-IRAN & North, West, Northwest \\
\hline A. austro-iranica Rech.f. & Fars: Kazeroun, Ghar-e Shahpur, 1000 m. & 22594-IRAN & West, South, Southwest \\
\hline $\begin{array}{l}\text { A. chamaecistus Ging. ex Benth subsp. } \\
\text { tomentella (Boiss.) Rech. f. (endemic) }\end{array}$ & $\begin{array}{l}\text { Kerman: Baft, Khabr Protected area, } \\
\text { Korikou, } 2300 \mathrm{~m} .\end{array}$ & 53855-IRAN & $\begin{array}{l}\text { West, Center, North, } \\
\text { Northwest }\end{array}$ \\
\hline $\begin{array}{l}\text { A. chamaecistus Ging. ex Benth subsp. } \\
\text { chamaecistus (endemic) }\end{array}$ & $\begin{array}{l}\text { Azerbaijan-W: Daryacheh-ye Orumieh, } \\
\text { Jazireh Kabudan, } 1320 \mathrm{~m} \text {. }\end{array}$ & 226001-IRAN & West, Center, Northwest \\
\hline
\end{tabular}




\section{Statistical analyses}

Nutlet morphometric data were subjected to one-way analysis of variance (ANOVA) to determine if significant variation existed among taxa for each characteristic measured. Mean and also standard deviations of all quantitative variables were calculated. The mentioned analyses were performed using SPSS ver. 17. Cluster analyses were carried out based on all of the studied characteristics using Unweighted Paired Group Method with Arithmetic Mean (UPGMA), Principal Coordinate Analysis (PCA), Principal Coordinate Ordination (PCO) and Correspondence Analysis (C.A-Joined) in Multivariate Statistical Package (MVSP) program (Podani 2000).

\section{RESULTS AND DISCUSSION}

\section{Results}

Nutlet qualitative and quantitative morphological characteristics of the studied taxa were summarized in Table 2. SEM micrographs of nutlet studied were presented in Figures 2 and 3. Some of the studied nutlet qualitative morphological characteristics varied among the studied taxa.

In most of studied taxa, nutlet shapes were oblong, except for A. orientalis, which was ovate. Furthermore, most of the studies taxa had indumentum on nutlet exocarp cell surface, except for A. chamaepitys subsp. chia var. ciliata and A. chamaecistus subsp. chamaecistus that no trichome was observed on the nutlet exocarp cell.

Nutlet sculpture of both ventral and dorsal surfaces was examined among the studied taxa. The sculpture pattern of ventral surfaces was similar among the taxa and was observed as reticulate. Although, different shapes of depressions such as elongated (A. austro-iranica), ovate (A. chamaepitys subsp. chila var. ciliata) or polygonal (the rest taxa) were reported.

However, dorsal surface sculpturing varied among the studied taxa and three types of sculpture existed on the dorsal surfaces of taxa nutlet: rugose (A. saxicola), reticulate-punctate $(A$. orientalis) and reticulate (the rest taxa).

The quantitative nutlet morphological variables differed among the studied taxa. Largest ventral $(7.47 \mathrm{~mm})$ and dorsal length $(8.07 \mathrm{~mm})$ were seen in A. chamaecistus subsp. chamaecistus, while A. austro-iranica had the smallest dorsal $(2.34 \mathrm{~mm})$ and ventral length $(2.46 \mathrm{~mm})$. Maximum dorsal $(3.35 \mathrm{~mm})$ and ventral $(2.66 \mathrm{~mm})$ width were registered in A. chamaecistus subsp. chamaecistus, however, the minimum dorsal and ventral width existed in A. saxicola.
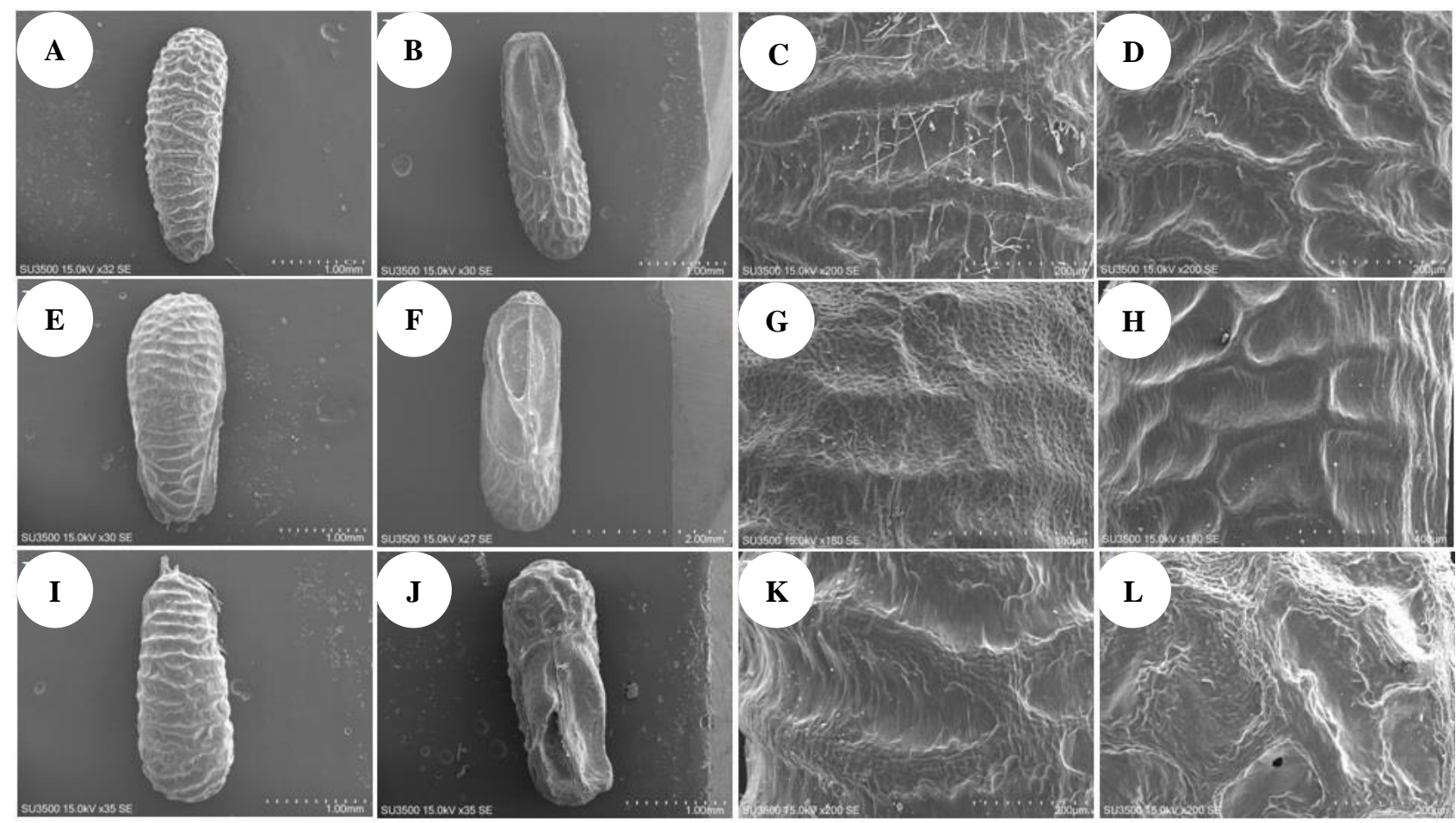

Figure 2. Scanning Electron Micrographs in Ajuga taxa. A. saxicola: A-B dorsal and ventral shape, C-D dorsal and ventral surface sculpturing, A. chamaepitys subsp. chia var. ciliata: E-F dorsal and ventral shapes, G-H dorsal and ventral surface sculpturing, A. austro-iranica; $\mathrm{I}-\mathrm{J}$ dorsal and ventral shape, $\mathrm{K}-\mathrm{L}$ dorsal and ventral surface sculpturing, respectively. 

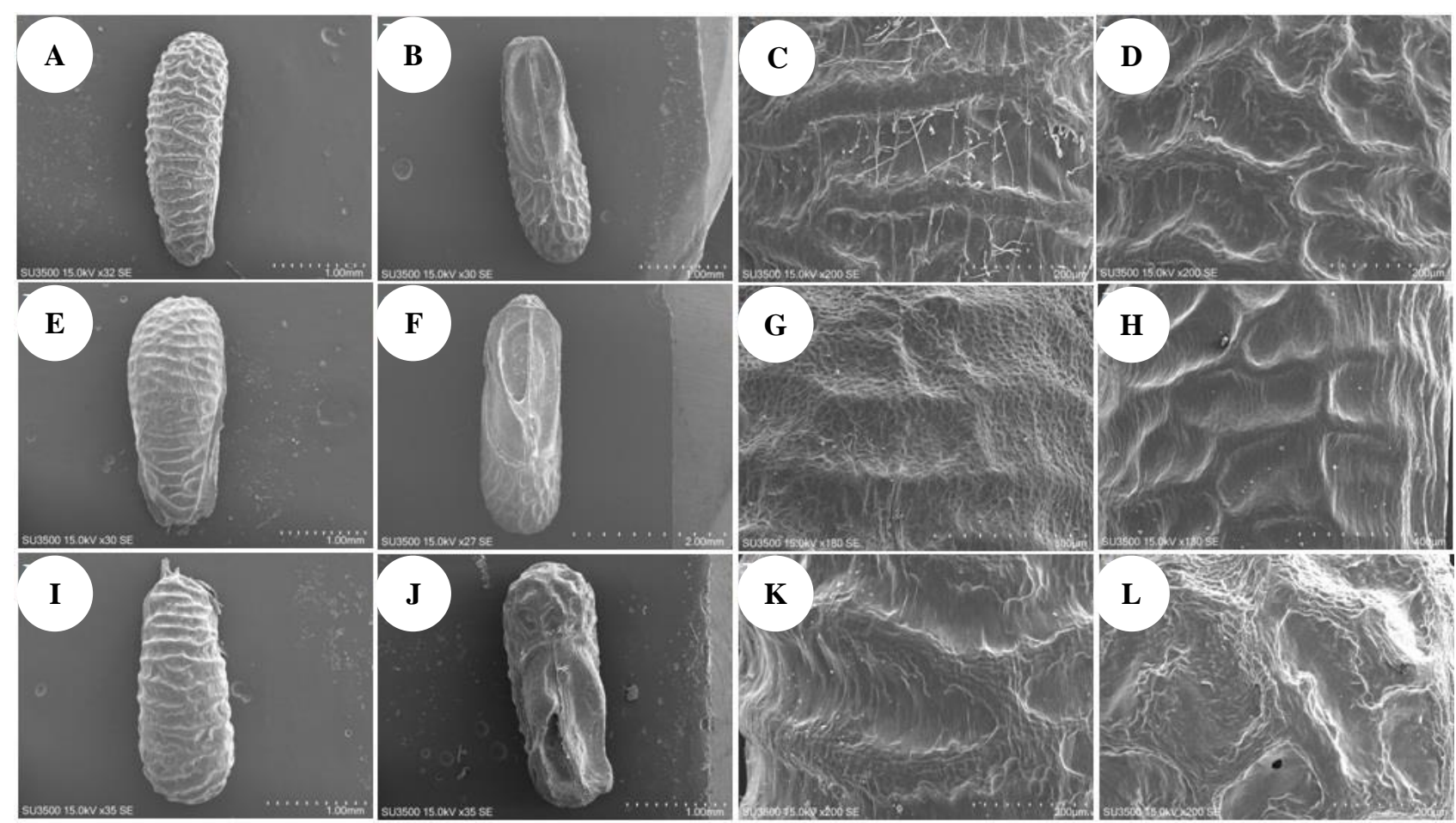

Figure 3. Scanning Electron Micrographs in Ajuga taxa. A. orientalis: A-B dorsal and ventral shape, C-D dorsal and ventral surface sculpturing, A. chamaecistus subsp. chamaecistus: E-F dorsal and ventral shape, G-H dorsal and ventral surface sculpturing, A. chamaecistus subsp. tomentella: I-J dorsal shape and surface sculpturing, K-L ventral shape and surface sculpturing, respectively.

In addition, the ANOVA test revealed significant difference $(\mathrm{p} \leq 0.01)$ for most of the studied quantitative nutlet features, except for aperture width (Table 3). Moreover, PCA analysis of these characteristics confirmed that nutlet ventral length and width with $47 \%$ and $21 \%$ of the total variations were the more variable traits, respectively.

The studied taxa clustered separately in UPGMA dendrogram of nutlet morphological variables (Figure 4). This dendrogram had two clades, A. chamaecistus subsp. chamaecistus was placed in the small clade and the other taxa were grouped in large clade, which was divided into two branches. A. orientalis was observed in the small branch, but the other branch had two sub-branches. Small sub-branches contained A. chamaecistus subsp. tomentella, however, large sub-branch had two groups, A. austroiranica and A. chamaepitys subsp. chila var. ciliata were clustered as a group, and another group consisted of $A$. saxicola.

Moreover, PCO and PCA plots produced similar results (Figures 5, 6). Therefore taxa arrangement in PCA plot was discussed here. In the plot, axis 1 divided the studied taxa into two groups, one of them was small and consisted of A. chamaecistus subsp. chamaecistus, and the other taxa were observed in the other large group. According to axis 2, the large group was divided into two sub-groups, A. austro-iranica and A. chamaepitys subsp. chia var. ciliata were as a group, which placed in the positive quadrate. While, A. orientalis and A. saxicola were in the negative quadrate.

CA-joined plot revealed that each group was characterized by special characteristic (s), which was useful in identification of them (Figure 7). For example, $A$. chamaecistus subsp. chamaecistus were identified by the largest nutlet length and width. 
Table 2. Some of the important nutlet morphological characteristics of the studied Ajuga taxa (all values are in mm)

\begin{tabular}{|c|c|c|c|c|c|c|c|c|c|c|c|c|}
\hline Taxa & $\begin{array}{l}\text { Ventral } \\
\text { length }\end{array}$ & $\begin{array}{l}\text { Ventral } \\
\text { width }\end{array}$ & $\begin{array}{c}\text { Ventral } \\
\text { length/width } \\
\text { ratio }\end{array}$ & $\begin{array}{l}\text { Dorsal } \\
\text { length }\end{array}$ & $\begin{array}{c}\text { Dorsal } \\
\text { width }\end{array}$ & $\begin{array}{l}\text { Dorsal } \\
\text { length/width } \\
\text { ratio }\end{array}$ & $\begin{array}{l}\text { Aperture } \\
\text { length }\end{array}$ & $\begin{array}{l}\text { Aperture } \\
\text { width }\end{array}$ & $\begin{array}{l}\text { Nutlet } \\
\text { shape }\end{array}$ & Indumentum & Dorsal sculpture & $\begin{array}{l}\text { Ventral } \\
\text { sculpture }\end{array}$ \\
\hline A. saxicola & $2.71 \pm 0.00$ & $0.89 \pm 0.02$ & $3.04 \pm 0.09$ & $2.52 \pm 0.00$ & $0.84 \pm 0.02$ & $2.98 \pm 0.07$ & $0.43 \pm 0.06$ & $0.16 \pm 0.02$ & Oblong & Present & Rugose & Reticulate \\
\hline A. orientalis & $2.69 \pm 0.03$ & $1.42 \pm 0.01$ & $1.89 \pm 0.005$ & $2.620 \pm 0.02$ & $1.36 \pm 0.01$ & $1.92 \pm 0.00$ & $0.27 \pm 0.08$ & $0.20 \pm 0.06$ & Ovate & Present & $\begin{array}{l}\text { Reticulate- } \\
\text { punctate }\end{array}$ & Reticulate \\
\hline $\begin{array}{l}\text { A. chamaepitys subsp. chia } \\
\text { var. ciliata }\end{array}$ & $3.12 \pm 0.007$ & $1.06 \pm 0.01$ & $2.94 \pm 0.03$ & $2.67 \pm 0.007$ & $1.13 \pm 0.01$ & $2.36 \pm 0.023$ & $0.82 \pm 0.01$ & $0.15 \pm 0.007$ & Oblong & Absent & Rugose & Reticulate \\
\hline A. austro-iranica & $2.46 \pm 0.007$ & $0.93 \pm 0.00$ & $2.65 \pm 0.007$ & $2.34 \pm 0.03$ & $0.96 \pm 0.02$ & $2.43 \pm 0.09$ & $0.73 \pm 0.23$ & $0.17 \pm 0.07$ & Oblong & Present & Reticulate & Reticulate \\
\hline $\begin{array}{l}\text { A. chamaecistus subsp. } \\
\text { tomentella }\end{array}$ & $3.40 \pm 0.14$ & $2.50 \pm 0.28$ & $1.36 \pm 0.09$ & $3.20 \pm 0.00$ & $1.26 \pm 0.007$ & $2.52 \pm 0.014$ & $0.80 \pm 0.12$ & $0.22 \pm 0.03$ & Oblong & Present & Reticulate & Reticulate \\
\hline $\begin{array}{l}\text { A. chamaecistus subsp. } \\
\text { chamaecistus }\end{array}$ & $7.47 \pm 0.05$ & $2.66 \pm 0.007$ & $2.80 \pm 0.01$ & $8.07 \pm 0.12$ & $3.35 \pm 0.07$ & $2.41 \pm 0.01$ & $0.60 \pm 0.04$ & $0.30 \pm 0.02$ & Oblong & Absent & Reticulate & Reticulate \\
\hline
\end{tabular}


Table 3. ANOVA test among the quantitative nutlet morphology characteristics of the studied taxa (abbreviations, ns: not significant, significant at $* * \leq 0.01, * \leq 0.05)$

\begin{tabular}{|c|c|c|c|c|c|c|}
\hline & & Sum of squares & df & Mean square & $\mathbf{F}$ & Sig. \\
\hline \multirow[t]{3}{*}{ Ventral length } & Between Groups & 36.414 & 6 & 6.069 & $1.699 \mathrm{E} 3$ & $0.000 * *$ \\
\hline & Within Groups & 0.025 & 7 & 0.004 & & \\
\hline & Total & 36.439 & 13 & & & \\
\hline \multirow[t]{3}{*}{ Ventral width } & Between Groups & 6.514 & 6 & 1.086 & 93.474 & $0.000 * *$ \\
\hline & Within Groups & 0.081 & 7 & 0.012 & & \\
\hline & Total & 6.595 & 13 & & & \\
\hline \multirow[t]{3}{*}{ Ventral length/ width ratio } & Between Groups & 4.500 & 6 & 0.750 & 258.323 & $0.000 * *$ \\
\hline & Within Groups & 0.020 & 7 & 0.003 & & \\
\hline & Total & 4.520 & 13 & & & \\
\hline \multirow[t]{3}{*}{ Dorsal length } & Between Groups & 49.893 & 6 & 8.315 & $2.209 \mathrm{E} 3$ & $0.000 * *$ \\
\hline & Within Groups & 0.026 & 7 & 0.004 & & \\
\hline & Total & 49.919 & 13 & & & \\
\hline \multirow[t]{3}{*}{ Dorsal width } & Between Groups & 8.769 & 6 & 1.462 & $1.562 \mathrm{E} 3$ & $0.000 * *$ \\
\hline & Within Groups & 0.007 & 7 & 0.001 & & \\
\hline & Total & 8.776 & 13 & & & \\
\hline \multirow[t]{3}{*}{ Dorsal length/width ratio } & Between Groups & 1.148 & 6 & 0.191 & 77.562 & $0.000 * *$ \\
\hline & Within Groups & 0.017 & 7 & 0.002 & & \\
\hline & Total & 1.165 & 13 & & & \\
\hline \multirow[t]{3}{*}{ Aperture length } & Between Groups & 0.765 & 6 & 0.128 & 10.342 & $0.003^{*}$ \\
\hline & Within Groups & 0.086 & 7 & 0.012 & & \\
\hline & Total & 0.852 & 13 & & & \\
\hline \multirow[t]{3}{*}{ Aperture width } & Between Groups & .035 & 6 & 0.006 & 2.809 & $0.101 \mathrm{~ns}$ \\
\hline & Within Groups & 0.014 & 7 & 0.002 & & \\
\hline & Total & 0.049 & 13 & & & \\
\hline \multirow[t]{3}{*}{ Aperture length/width ratio } & Between Groups & 28.360 & 6 & 4.727 & 14.538 & $0.001 * *$ \\
\hline & Within Groups & 2.276 & 7 & 0.325 & & \\
\hline & Total & 30.636 & 13 & & & \\
\hline
\end{tabular}

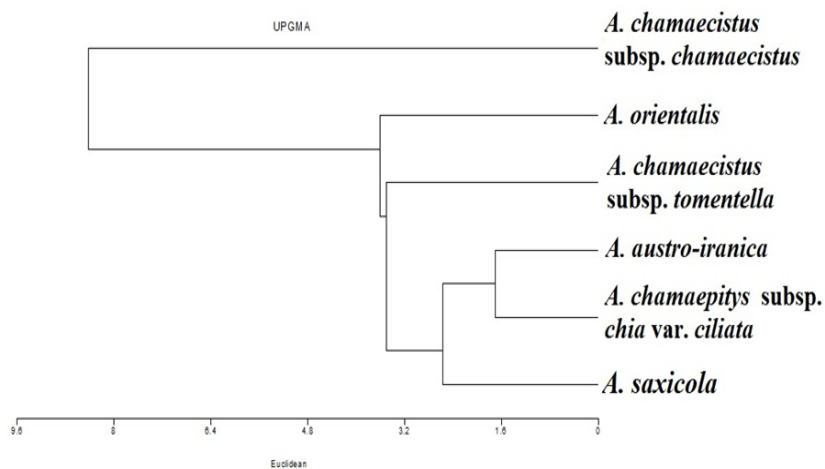

Figure 4. UPGMA dendrogram of six Ajuga taxa based on the nutlet morphological characteristics

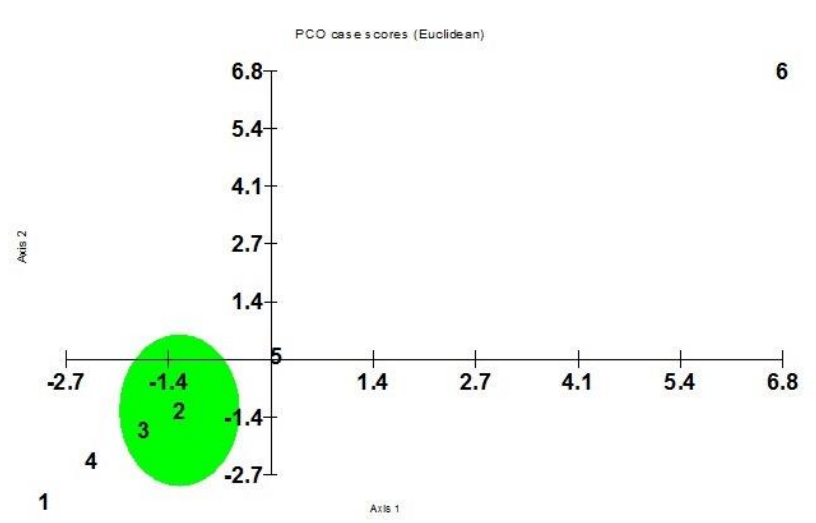

Figure 5. PCO plot of the studied Ajuga taxa based on the nutlet characteristics (numbers are taxa names according to Table 1) 


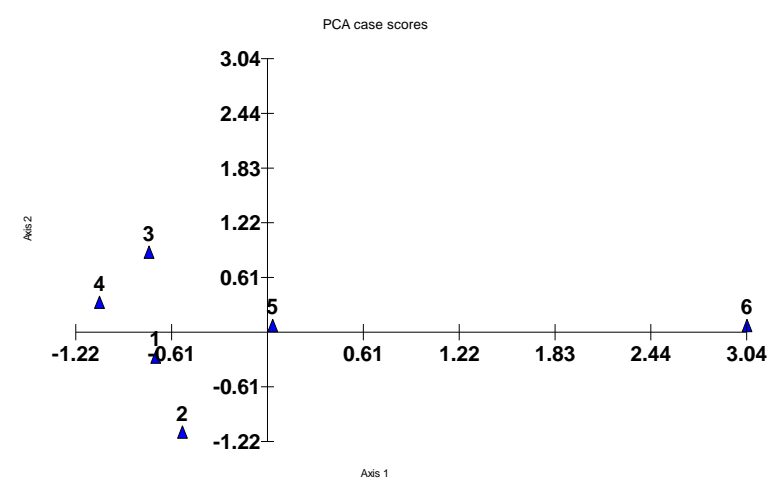

Figure 6. PCA plot of the studied Ajuga taxa based on nutlet features (numbers indicate taxa names according to Table 1)

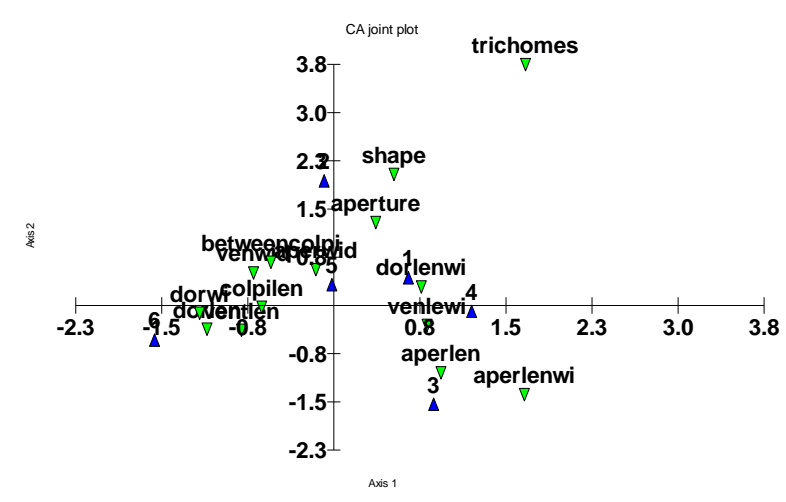

Figure 7. CA-joined plot of the nutlet morphological features with studied taxa of Ajuga (numbers are taxa names according to Table 1 and green symbols are characteristics name)

\section{Discussions}

In the current study, we used nutlet morphological characteristics in order to taxonomical treatment of infrageneric variations in some Ajuga taxa in Iran. Because, nutlet characteristics such as surface sculpturing have been shown to be of systematic value in several groups of Lamiaceae (Husain et al. 1990; Oran 1996). For example, Guerin (2005) examined nutlet morphological features of Hemigenia R.Br. and Microcorys R.Br. They reported that characteristics such as shape of nutlet, nature of attachment scar and surface sculpturing, shape of exocarp cell and sculpturing, and absence or presence of indumentum are potential of great phylogenetic value.

Some of the studied qualitative nutlet characteristics such as surface sculpturing varied among the studied taxa and had taxonomic value in identification of taxa. For example, existence of indumentum on the nutlet surface was a good trait for identification of two subspecies of $A$. chamaecistus. A. chamaecistus subsp. tomentella had trichome on its nutlet exocarp cell surface, while nutlet exocarp cell surface of A. chamaecistus subsp. chamaecistus was glabrous. These conditions were reported from different genera of Lamiaceae. For example, the density of glandular trichomes is the most useful feature in Teucrium (Marin et al. 1994). Furthermore, in other genera, such as Lycopus (Moon and Hong 2006) and Scutellaria (Turner and Delprete 1996) the distribution of glandular trichomes is one of the most important variables in delimitation of taxa at specific and infraspecific levels.

However, some qualitative features of Ajuga nutlet, like shape, were nearly stable and had no taxonomic value at infrageneric/infraspecific ranks. Our findings were in agreement with previous studies on different Lamiaceae taxa. For example, Husain et al. (1990) suggested that some variables such as nutlet shape are invariable in some taxonomical groups like tribe Saturejeae.

Beside, Oran (1996) has suggested that in Salvia L. species (one of the largest genera of Lamiaceae) the gross morphology of nutlets and its sculpturing pattern are variable and taxonomically very useful. Although, some characteristics such as nutlets color, size, and shape were not considered as taxonomically important features, either because these variables did not vary or the variation was random or too great.

We investigated sculpturing pattern of both dorsal and ventral surface of nutlet. Although, the ventral sculpturing was nearly stable among the studied taxa, the dorsal pattern differed significantly among the taxa and had taxonomic value in identification of species or infraspecific taxa. These conditions were reported from different genera of Lamiaceae. For instance, in Salvia L. species the nutlet sculpturing type has been considered to be taxonomically most important (Oran 1996). Demissew and Harley (1992) reported that difference in nutlet sculpturing and morphology of exocarp cellular gives evidence for a classification of Stachys species into three groups.

The studied taxa were clustered separately in UPGMA dendrogram and also PCA and PCO plots of the nutlet characteristics. According to the nutlet features, theses taxa were divided into four groups: group 1 including: $A$. chamaepitys subsp. chia var. ciliata, A. saxicola and A. austro-iranica, group 2 contained A. chamaecistus subsp. tomentella, group 3 had $A$. orientalis, and group 4 was composed of A. chamaecistus subsp. chamaecistus. Similar results were reported by Köse et al. (2018). They used ITS1-5.8S-ITS4 (ITS) for investigation phylogenetic relation among eleven Ajuga taxa in Turkey. Only two species (A. chamaepitys subsp. chia and A. orientalis) were similar between the current study and their work. In both studies, these taxa placed far from each other.

In addition, A. chamaecistus subsp. tomentella and A. chamaecistus subsp. chamaecistus were clustered far from each others. Different synonyms were definite for subsp. chamaecistus such as A. tomentella and A. salicifolia. var. tomentella. It seems that the decrement taxonomic rank of A. tomentella to subspecies, or its taxonomic positions from A. salicifolia var. tomentella have not corrected. According to UPGMA dendrogram, A. chamaepitys subsp. chia var. ciliata, A. saxicola and A. austro-iranica closely related and made a group. These taxa are morphologically similar (Jamzad 2012). There have been many discussions about taxonomic positions of A. austro-iranica, and several synonyms have been definite for it such as A. chamaepitys subsp. tridactylites (Ging. Ex Benth.) Davis (Rechinger 1982). Furthermore, A. saxicola was recently recorded for 
Iran by Jamzad and Assadi (1984). It does not seem to be a mistake to redefine $A$. saxicola and A. austro-iranica as infraspecific taxa of $A$. chamaepitys. These findings agreed with Köse et al. (2018) morphological study. They have suggested that A. chamaepitys (sensu lato) is an annual, biennial or perennial plant and very variable morphologically. Stems may be prostrate or ascending, variously hairy or glabrous. There is no absolutely sharp line of morphological differentiation between different subspecies of A. chamaepitys. For instance, leaf and indumentum that are affected by ecological conditions are often used in the diagnosis of their subspecies. However, according to Köse et al. (2018), it may be necessary to employ different molecular techniques to attain specieslevel discrimination across all Ajuga species.

\section{In conclusion}

, we evaluated nutlet morphological characteristics using SEM; our results revealed that most of the studied quantitative characteristics significantly varied among the studied taxa. Among the qualitative characteristics, nutlet shape and ventral surface sculpturing were nearly stable, while dorsal sculpturing pattern and absence or presence of indumentum could be used as taxonomic variables for identification of the studied taxa. Four distinct groups were observed in UPGMA dendrogram and PCO and PCA plots of the nutlet characteristics and each of them was characterized by special variable(s). Species clustering, in several cases, were not similar to those were proposed in Flora Iranica and Flora of Iran. It seems that taxonomic positions of some infraspecific taxa must be changed and redefine.

\section{REFERENCES}

Atay I, Kirmizibekmez H, Kaiser M, Akaydin G, Yesilada, E, Tasdemir D. 2016. Evaluation of in vitro antiprotozoal activity of Ajuga laxmannii and its secondary metabolites. Pharm Biol 54: 1808-1814.

Barthlott W. 1984. Microstructural features of seed surfaces. In: Heywood VH, Moore DM (eds.) Current Concepts in Plant Taxonomy. Academic Press, London.

Cantino PD. 1992. Evidence for a polyphyletic origin of the Labiatae. Ann Missouri Bot Gard 79: 361-379.

Cocquyt K, Cos P, Herdewijn P, Maes L, Van Den Steen PE, Laekeman G. 2011. Ajuga remota Benth.: From ethnopharmacology to phytomedical perspective in the treatment of malaria. Phytomedicine 18: $1229-1237$.

Demissew S, Harley MM. 1992. Trichome, seed-surface and pollen characters in Stachys, Lamioideae (Labiatae) in Tropical Africa. In Harley RM, Reynolds T (eds) Advances in Labiatae Science. Royal Botanical Gardens, Kew.

El-Hilaly J, Tahraoui A, Israili ZH, Lyoussi B. 2006. Hypolipidemic effects of acute and sub-chronic administration of an aqueous extract of Ajuga iva L. whole plant in normal and diabetic rats. J Ethnopharmacol 105: 441-448.

Guerin GR. 2005. Nutlet morphology in Hemigenia R. BR. Microcorys R. BR. (Lamiaceae). Plant Syst Evol 254: 49-68.

Güneş F, Özhatay N. 2011. An ethnobotanical study from Kars (Eastern) Turkey. Biol Divers Conserv 4 (1): 30-41.
Husain SZ, Marin PD, Šilić C, Qaiser M, Petković B. 1990. A micromorphological study of some representative genera in the tribe Saturejeae (Lamiaceae). Bot J Linn Soc 103: 59-80.

Israili ZH, Lyoussi B. 2009. Ethnopharmacology of the plants of genus Ajuga. Pak J Pharm Sci 22: 425-462.

Jamzad Z. 2012. Flora of Iran, No. 76: Lamiaceae. Ministry of Jihad-eAgriculture, Research Institute of Forests \& Rangelands Press, Iran.

Jamzad Z, Assadi A. 1984. New species of the genera Nepeta and Ajuga (Labiatae) from Iran. Iran J Bot 2 (2): 95-102.

Judd WS, Campbell CS, Kellog EA, Stevens PF. 2008. Plant Systematics: A Phylogenetic Approach. Sinauer Associates, Sunderland

Köse YB, Mutlu MB, Küçük S. 2018. Phylogenetic relationships of some Ajuga L. taxa based on the ribosomal DNA internal transcribed spacer region. Rom Biotechnol Lett 23 (1): 13249-13254.

Koyuncu O, Yaylac ÖK, Öztürk D, Erkara İP, Savaroğlu F, Akcoşkun Ö, Ardıç M. 2010. Risk categories and ethnobotanical features of the Lamiaceae taxa growing naturally in Osmaneli (Bilecik/Turkey) and environs. Biol Divers Conserv 3 (3): 31-45.

Marin PD, Petković BP, Duletic S. 1994. Nutlet sculpturing of selected Teucrium species (Lamiaceae): A character of taxonomic significance. Pl Syst Evol 192: 199-214.

Moon HK, Hong SP. 2006. Nutlet morphology and anatomy of the genus Lycopus (Lamiaceae. Mentheae). Plant Res J 119: 633-644.

Movahhedin N, Zengin G, Bahadori MB, Sarikurkcu C, Bahadori S, Dinparast L. 2016. Ajuga chamaecistus subsp. scoparia (Boiss.) Rech.f.: A new source of phytochemicals for antidiabetic, skincare and neuroprotective uses. Ind Crops Prod 94: 89-96.

Oran SA. 1996. Ultrastructure of nutlet surface of the genus Salvia L. in Jordan and the neighboring countries. Dirasat Nat Eng Sci 23: 393-408.

Podani J. 2000. Introduction to the Exploration of Multivariate Data. Backhuyes, Leide.

Rechinger K. 1982. Labiatae In: Flora Iranica. No. 150, Akademische Druch-u, Verlagsanstat, Austria

Riaz N, Nawaz SA, Mukhtar N, Malik A, Afza N, Ali S, Ullah S, Muhammad P, Choudhary MI. 2007. Isolation and enzyme-inhibition studies of the chemical constituents from Ajuga bracteosa. Chem Biodivers 4: 72-83.

Roth I. 1977. Fruits of angiosperms. Encyclopedia of Plant Anatomy. Gebriider Borntraeger, Berlin-Stuttgart.

Ryding O. 1993. Pericarp structure of Leucas and related genera (Lamiaceae subfam. Lamioideae). Nord J Bot 13: 637-646.

Ryding O. 1994. Pericarp structure and phylogeny of Lamiaceae subfamily Pogostemonoideae. Nord J Bot 14: 59-63.

Ryding O. 1998. Phylogeny of the Leucas group (Lamiaceae). Sys Bot 23 (2): 235-237.

Sarac N, Ugur A. 2007. Antimicrobial activities and usage in folkloric medicine of some Lamiaceae species growing in Mugla, Turkey. Eurasia J Biosci 4: 28-37.

Stace CA. 1989. Plant Taxonomy and Biosystematics, 2nd ed. Edward Arnold, London.

Stearn WT. 1992. Botanical Latin. David \& Charles, Newton Abbot.

Toiu A, Mocan A, Vlase L, Pârvu AE, Vodnar DC, Gheldiu AM, Moldovan C, Oniga I. 2018. Phytochemical composition, antioxidant, antimicrobial and in vivo anti-inflammatory activity of traditionally used Romanian Ajuga laxmannii (Murray) Benth. ("Nobleman's Beard"-Barba Împaratului). Front Pharmacol 9: 1-15.

Turner BL, Delprete PG. 1996. Nutlet sculpturing in Scutellaria sect. Resinosa (Lamiaceae) and its taxonomic utility. Plant Syst Evol 199: 109-120.

Tümen G, Malyer H, Başer KHC, Öz Aydın S. 2006. Plants used in Anatolia for wound healing. Proceedings of the IVth International Congress of Ethnobotany, Istanbul.

Venditti A, Frezza C, Maggi F, Lupidi G, Bramucci M, Quassinti L, Giuliani C, Cianfaglione K, Papa F, Serafini M, Bianco A. 2016. Phytochemistry, micromorphology and bioactivities of Ajuga chamaepitys (L.) Schreb. (Lamiaceae, Ajugoideae): Two new harpagide derivatives and an unusual iridoid glycosides pattern. Fitoterapia 113: 35-43. 